Systematic Review

\title{
Music-Induced Analgesia in Chronic Pain Conditions: A Systematic Review and Meta- Analysis
}

Eduardo A. Garza-Villarreal, MD, PhD ${ }^{1,2}$, Victor Pando, MD ${ }^{1,3,4}$, Peter Vuust, PhD², and Christine Parsons, $\mathrm{PhD}^{2}$

\footnotetext{
From: ${ }^{2}$ Subdirección de Investigaciones Clínicas, Instituto Nacional de Psiquiatría "Ramon de la Fuente Muñíz", Mexico City, Mexico; ${ }^{2}$ Center for Music in the Brain, University of Aarhus, Denmark; 3Universidad Nacional Autónoma de México, Mexico City, Mexico; 4 Instituto de Neurobiología, Universidad Nacional Autónoma de México,

Juriquilla, Queretaro, Mexico

Address Correspondence: Eduardo A. Garza-Villarreal Subdirección de Investigaciones Clínicas, Instituto Nacional de Psiquiatría "Ramon de la Fuente Muñiz", Calzada MexicoXochimilco 101, San Lorenzo Huipulco, Tlalpan, CP 14370 Mexico City, Mexico

Email: egarza@imp.edu.mx

Disclaimer: There was no external funding in the preparation of this manuscript. Conflict of interest: Each author certifies that he or she, or a member of his or her immediate

family, has no commercial association (i.e., consultancies, stock ownership, equity interest, patent/licensing arrangements, etc.) that might pose a conflict of interest in connection with the submitted manuscript.

Manuscript received: 03-10-2017 Revised manuscript received: 05-11-2017

Accepted for publication: 06-02-2017

Free full manuscript:

Background: Music is increasingly used as an adjuvant for the management of chronic pain (CP), as it is non-invasive, inexpensive, and patients usually report positive experiences with it. However, little is known about its clinical efficacy in chronic pain patients.

Objectives: We aimed to determine the effect of music as an adjuvant for chronic pain, as well as to identify characteristics of music interventions associated with positive clinical outcomes.

Study Design: In this systematic review and meta-analysis, we investigated randomized controlled trials (RCTs) of adult patients that reported any type of music intervention for chronic pain, chosen by the researcher or patient, lasting for any duration. Searches were performed using PsycINFO, Scopus, and PubMed for RCTs published until the end of May 2016. The primary outcome was reduction in self-reported pain using a standardized pain measurement instrument, reported post-intervention. The secondary outcomes were: quality of life measures, depression, anxiety, and related measures.

Methods: The study was pre-registered with PROSPERO (CRD42016039837), and the metaanalysis was performed using RevMan 5.3 (The Nordic Cochrane Centre for The Cochrane Collaboration, Copenhagen, Denmark). We identified 768 titles and abstracts, and we included 14 RTCS that fulfilled our criteria. The sample size of the studies varied between 25 and 200 patients.

Results: We found that music reduced self-reported chronic pain and depressive symptoms. We also found that music had a greater effect when the patient chose the music, compared to when the researcher chose it.

Limitations: The sample size of RCTs was small and sometimes with different outcome measures. There was high heterogeneity associated with pooled estimates.

Conclusions: Our analysis suggests that music may be beneficial as an adjuvant for chronic pain patients, as it reduces self-reported pain and its common comorbidities. Importantly, the analgesic effect of music appears higher with self-chosen over researcher-chosen music.

Key Words: Pain, music, analgesia, music-induced analgesia, chronic pain, meta-analysis, systematic review, therapy

Pain Physician 2017; 20:597-610

www.painphysicianjournal.com
}

hronic pain (CP) is highly prevalent worldwide, although estimates vary considerably across countries (1-3). It is an important socioeconomical and health problem due to the secondary disability and comorbidities such as anxiety, depression, and suicide, as well as the high rate of dependency on opioid painkillers. It is estimated that between $10-50 \%$ of patients with CP suffer mild to 
severe secondary disability, and CP is one of the leading causes of years lived with disability according to the Global Burden Disease study (4). Furthermore, there is evidence that addiction to painkillers can be a route to heroin dependency (5). For these reasons, there is a need for adjuvant therapies that help to reduce pain, its comorbidities, and particularly, to reduce or avoid painkiller dependency.

The most accepted hypothesis states that pain perception can be centrally modulated via the descending pain modulatory system (DPMS) by either inhibiting or facilitating nociceptive input at the brainstem and spinal cord level (6). The DPMS can be affected by many intrinsic factors including: expectation, attention, context, sensitization, emotion, mood, chemical pathways (neurotransmitter dysfunction), and even genetics (7). A number of studies have shown the analgesic effects of music in acute experimental pain (8-11). The underlying mechanisms for the so-called "music-induced analgesia" may not be specific to music, but surely related to the DPMS (12). Music characteristics such as: high familiarity (8), few beats-per-minute (13), and self-chosen music (14), have been reported to elicit cognitive and emotional mechanisms such as: distraction (15), pleasure (16), sense of control (7), and placebo-like effects (17) that may contribute to the analgesic effect, all of which can affect the DPMS. It is therefore possible that music provides an easily accessible and strong medium for top-down influence of the DPMS, thus reducing pain. If this hypothesis is correct, then characteristics of the "music treatment" such as music genre or delivery (listening or performing) may be less relevant for the analgesic effect and personal preference may be more important instead.

The interest in music for the management of chronic pain during or after hospitalization is growing (18-20), but its use is far from routine. A growing number of studies have supported the use of music as an adjuvant (21-23). A recent meta-analysis by Hole et al (21), published in Lancet in 2015, highlighted the importance of listening to music as an aid for postoperative recovery, as it reduces pain and anxiety. Nevertheless, an assessment of study quality and synthesis of findings is clearly warranted, especially in the subject of chronic pain. Providing evidence of its potential effect could encourage physicians and healthcare professionals to use it more widely with this population. In this systematic review and meta-analysis, we aim to assess the effect of music as an adjuvant for chronic pain, as well as the characteristics of the music, if any, with the better clinical response. For this we assessed evidence for the efficacy of music in reducing pain and comorbidities, such as anxiety and depression, in randomized controlled trials (RCTs) treating chronic pain patients. We also investigated a priori identified subgroups such as: patient familiarity with the music, experimenterchosen versus self-chosen music, and the type of pain condition.

\section{Methods}

This meta-analysis and systematic review followed procedures from the Cochrane Handbook for Systematic Reviews (24) and from the Center for Reviews and Dissemination (Centre for Reviews and Dissemination, 2014). The review protocol is registered with PROSPERO No. [CRD42016039837].

\section{Search Strategy}

Searches were performed using PsycINFO, Scopus, and PubMed for RCTs that reported on a music intervention for chronic pain published until the end of May of 2016. The search terms were prevalent chronic pain conditions obtained from the International Association for the Study of Pain (IASP) (www.iasp-pain.org/PublicationsNews/Content.aspx? ItemNumber $=1673 \&$ navltemN umber=677) and the MeSH terms for these (for details and search strings see Supplementary Materials). Only RCTs with adults aged $18-70$ years old were included. Exclusion criteria were: not using an RCT design, acute rather than chronic pain conditions, and testing a pediatric population. At full-text review, the studies were checked to ensure the reporting of results from unique, non-overlapping patients. We included studies that reported any type of music intervention for chronic pain: active music playing, listening to music (passive), or 'music medicine,' chosen by the researcher or patient, and lasting for any duration. Chronic pain was defined as pain persisting or recurring for more than 12 weeks (25). Pain conditions were broadly defined to encompass all types of pain according to the terms by the IASP. The primary outcome was reduction in self-reported pain using standardized pain measurement instruments such as: the visual analog scale (VAS), the numerical rating scale (NRS), the McGill Pain Questionnaire, and the West Haven-Yale Multidisciplinary Pain Inventory, reported post-intervention (26). The secondary outcomes were: quality of life measures, psychological health (depression and anxiety measures), and physical health (such as pain-related disability), reported post-intervention, as well as longer-term intervention outcomes, 
if available. The comparisons/controls were as follows: wait list control, no music control, and active control; hence, there were no restrictions placed on the control.

\section{Data Extraction and Synthesis}

Information was extracted from each study as follows:

The characteristics of the study where relevant, including the year of publication, design, randomization, blinding, number of participants, attrition, type of outcome measures, and overall treatment effects (2) The characteristics of the intervention: the type of music, list of songs or any other detail on music included, the duration of the music intervention, measures of patient engagement and enjoyment, and the qualifications/ background of the individual(s) delivering the intervention, if relevant (3) The characteristics of the patients: gender, age, drop-outs, length of pain condition, and comorbid conditions.

To avoid risk of bias, 2 reviewers (VP and EGV) independently assessed the methodological quality of the included RCTs using the Cochrane Risk of Bias tool. We also assessed for risk of publication bias. We performed a sensitivity analysis, removing studies at high-risk of bias. Any disagreements that arose between the reviewers were resolved through discussion or with a third reviewer (CEP).

To analyze the association between intervention and outcome and to avoid variability from the different pain measurement instruments and missing data, we used the primary outcome post-intervention as reported by the study investigators and calculated the effect size. Only in one study (27), the post-intervention improvement was shown as an increase in the pain variable, hence the effect size was calculated backwards. If any of the studies showed pain reduction as a secondary outcome of interest, we considered it the primary outcome for our analyses. Statistical analyses, including pooled mean home practice data, meta regression, and risk of bias, were conducted using RevMan 5.3 (The Nordic Centre for The Cochrane Collaboration, Copenhagen, Denmark) (28). An estimation of heterogeneity was calculated.

\section{Subgroup Analyses}

We investigated several a priori identified subgroups of interest: "primary vs. secondary pain," "central vs. peripheral pain," "long-term chronic pain conditions ( $>5$ years) vs. short-term pain conditions," and "patient-selected vs. researcher-selected music." We conducted the subgroup analyses using difference of means. Post-hoc, we removed the "primary vs. secondary pain" contrast because the terms are not commonly used, and we also removed "long-term vs. short-term pain" contrast due to the low sample size for the latter $(n=1)$. Instead, we included the contrast "etiology of pain" that includes IASP categories: neoplasm, degenerative/mechanical, inflammatory, unknown etiology, and combined etiology (studies that included 2 or more pathologies). We also studied the contrast intervention "familiar vs. unfamiliar music." Finally, we added "music delivery" (recorded music, live music, or active music) as a subgroup contrast of interest.

\section{Study Characteristics}

Figure 1 shows the Preferred Reporting Items for Systematic Reviews (PRISMA) flow chart for the included studies. A total of 65 studies were identified that reported a music intervention for chronic pain ( $\mathrm{n}$ $=768$ ). Of those, 14 studies fulfilled our criteria and/or provided data when contacted. Eleven studies investigated pain reduction as a primary outcome, while 3 investigated pain as a secondary outcome. The characteristics of the included studies are shown in Table 1. From those, 11 studies were RCTs in which they randomly allocated the patients to the music intervention group or the standard care group (18,29-37). In 3 studies the comparison group was: 1) standard care plus reading or conversing with the patient (38), 2) standard care plus listening to a metronome (27), and 3) standard care plus vibration in acupuncture pressure points using a specialized device (39). The sample size of the studies varied between 25 and 200 patients $(M=84, S D=47)$. The total sample of patients included for this review and meta-analysis was 1,178 . The majority of the included studies examined patients experiencing either cancer pain (4/14) or fibromyalgia (3/14), but a variety of other patient groups were also examined (palliative care, osteoarthritis, multiple sclerosis, chronic non-malignant pain [CNMP], and inflammatory bowel disease). The mean age of the included patients was 55 years ( \pm 10.8 ), and the mean length of pain condition was 7.3 years $( \pm 4.1)$. The mean music duration in the included studies was 30 minutes $( \pm 10.05)$, with $80 \%$ of them between $20-30$ minutes long. The majority of studies with recorded music intervention used headphones for delivery (7/11), while the others used CD players.

The music delivery was performed by the patient in most studies (7/14), while in others the intervention was delivered by a trained researcher, a trained 


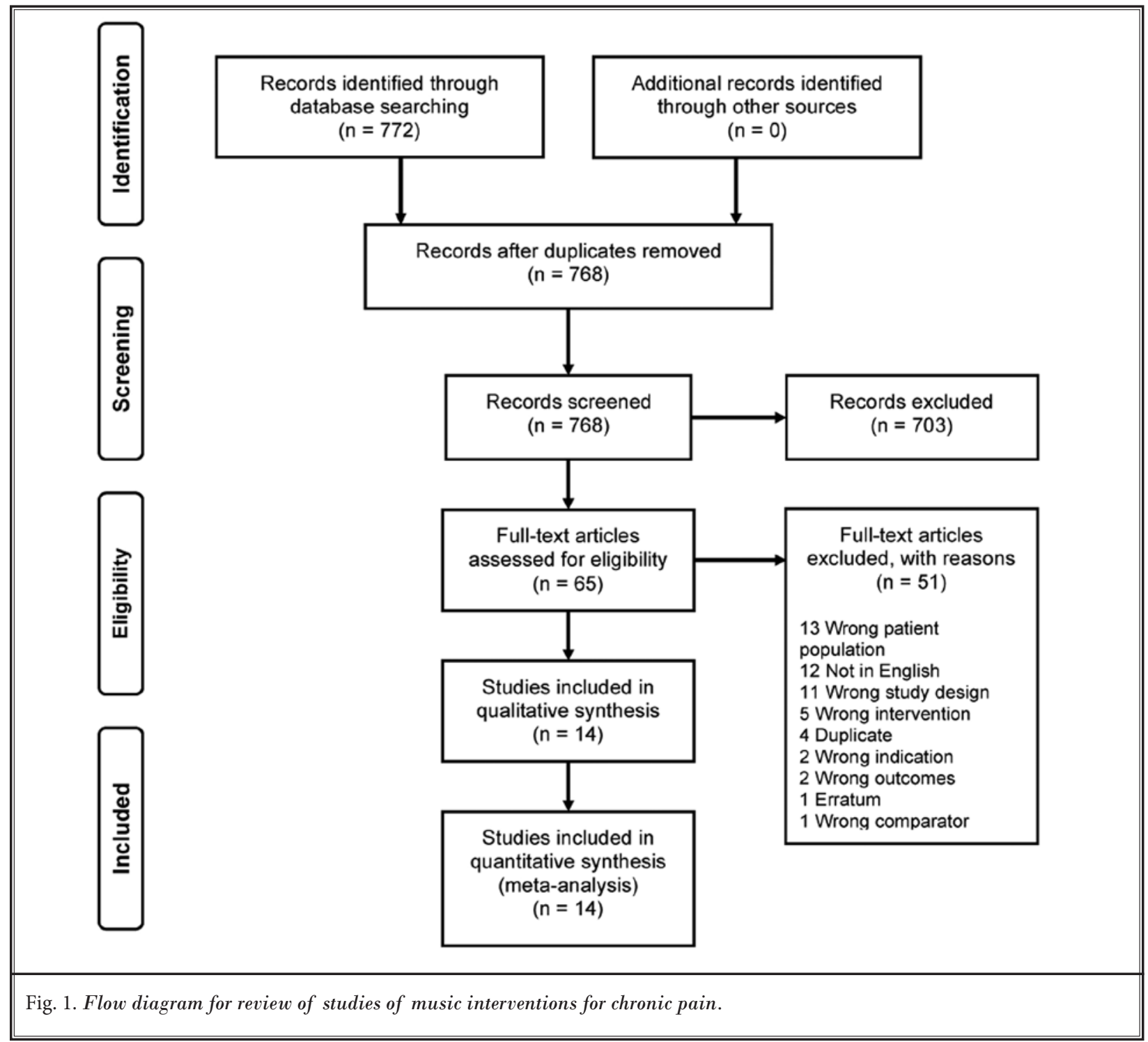

nurse, or a music therapist. The music was delivered via recorded tapes in the majority of cases (11/14) or live music (2/14). One study was considered "active music," as choir singing was the intervention (1 out of 14). Only 2 studies (14\%) reported "music enjoyment" as a variable, both reporting patients' liking of music as $>90 \%$ $(33,35)$. Neither study stated the method used to assess music enjoyment. The timing of delivery was anytime of the day, including moments with increased perceived pain. We identified some genres of music delivered: Chinese classical music, Swedish songs, Taiwanese folk songs, Buddhist music, classical western music, jazz, and pop, as well as instrumental and ambient music such as: ocean drum, harp, piano, orchestra, and water and wave sounds. Therefore, the music genre varied greatly between studies.

Comparator/control descriptions varied and include several different ones: no music (11/14), tactile touch (1/14), conversation (1/14), and routine patient care (1/14). Pain was usually measured with the VAS $(10 / 14)$, but other scales were used such as the NRS (1/14), functional pain scale (1/14), and pain rating index (PRI) (1/14). Secondary outcomes were measured with a variety of scales, such as: the Hospital Anxiety and Depression Scale (40), the Edmonton Symptom Assessment System (41), the Beck Depression Inventory 
Music-Induced Analgesia in Chronic Pain Conditions

Table 1. Characteristics of the studies included in the meta-analysis evaluating music for chronic pain.

\begin{tabular}{|c|c|c|c|c|c|c|c|}
\hline Study & Country & Patients & Sample & Intervention & Control & Qualification & Tools \\
\hline $\begin{array}{l}\text { Alparslan et al } \\
(2016)(18)\end{array}$ & Turkey & Fibromyalgia & $\begin{array}{l}\mathrm{n}=37 \\
\text { mean age }=43.59 \\
95 \% \text { female }\end{array}$ & Recorded music & Standard care & $\begin{array}{l}\text { Patient- } \\
\text { administered }\end{array}$ & pVAS $(0-10)$ \\
\hline $\begin{array}{l}\text { Burrai et al } \\
(2014)(29)\end{array}$ & Italy & Cancer & $\begin{array}{l}\mathrm{n}=52 \\
\text { mean age }=64.5 \\
83 \% \text { female }\end{array}$ & Live music & Standard care & Trained nurse & $\begin{array}{l}\text { mVAS } \\
(0-10), \text { pVAS } \\
(0-10, \mathrm{BP} \\
\end{array}$ \\
\hline $\begin{array}{l}\text { Clark et al } \\
(2006)(30)\end{array}$ & USA & Cancer & $\begin{array}{l}\mathrm{n}=63 \\
\text { mean age }=57.79 \\
38 \% \text { female }\end{array}$ & Recorded music & Standard care & Music therapist & $\begin{array}{l}\text { dNRS (0-10), } \\
\text { pNRS }(0-10), \\
\text { HADS, } \\
\text { POMS }\end{array}$ \\
\hline $\begin{array}{l}\text { Grape et al } \\
(2009)(31)\end{array}$ & Sweden & $\begin{array}{l}\text { Irritable Bowel } \\
\text { Syndrome }\end{array}$ & $\begin{array}{l}\mathrm{n}=55 \\
\text { mean age }=\text { not } \\
\text { reported, gender } \\
\text { not reported }\end{array}$ & Active music & Standard care & $\begin{array}{l}\text { Patient- } \\
\text { administered }\end{array}$ & $\begin{array}{l}\text { VAS }(0-10) \text {, } \\
\text { BP }\end{array}$ \\
\hline $\begin{array}{l}\text { Guétin et al } \\
(2012)(32)\end{array}$ & France & CNMP & $\begin{array}{l}\mathrm{n}=87 \\
\text { mean age }=48.85, \\
78 \% \text { female }\end{array}$ & Recorded music & Standard care & Trained nurse & $\begin{array}{l}\text { VAS }(0-10), \\
\text { HADS, pNRS } \\
(0-10)\end{array}$ \\
\hline $\begin{array}{l}\text { Gutgsell et al } \\
(2013)(20)\end{array}$ & USA & Palliative care & $\begin{array}{l}\mathrm{n}=200 \\
\text { mean age }=56.09 \\
69 \% \text { female }\end{array}$ & Live music & Standard care & Music therapist & $\begin{array}{l}\text { pNRS }(0-10), \\
\text { FLACCS, } \\
\text { FPS }(0-5)\end{array}$ \\
\hline $\begin{array}{l}\text { Horne- } \\
\text { Thompson } \\
(2008)(38)\end{array}$ & Australia & Palliative care & $\begin{array}{l}\mathrm{n}=25 \\
\text { mean age }=73.9, \\
44 \% \text { female }\end{array}$ & Recorded music & $\begin{array}{l}\text { Reading or } \\
\text { conversation + } \\
\text { standard care }\end{array}$ & Music therapist & $\begin{array}{l}\text { ESAS }(0-10) \text {, } \\
\text { BP }\end{array}$ \\
\hline $\begin{array}{l}\text { Huang et al } \\
(2010) \text { (33) }\end{array}$ & Taiwan & Cancer & $\begin{array}{l}\mathrm{n}=126 \\
\text { mean age }=54, \\
29 \% \text { female }\end{array}$ & Recorded music & Standard care & Trained nurse & VAS $(0-100)$ \\
\hline $\begin{array}{l}\text { Li et al (2011) } \\
\text { (34) }\end{array}$ & China & Cancer & $\begin{array}{l}\mathrm{n}=120 \\
\text { mean age }=45.01, \\
100 \% \text { female }\end{array}$ & Recorded music & Standard care & $\begin{array}{l}\text { Trained } \\
\text { researcher }\end{array}$ & $\begin{array}{l}\text { VAS }(0-10) \text {, } \\
\text { PPI }(0-5) \text {, } \\
\text { PRI }\end{array}$ \\
\hline $\begin{array}{l}\text { McCaffrey } \\
(2003)(35)\end{array}$ & USA & Osteoarthritis & $\begin{array}{l}\mathrm{n}=66 \\
\text { mean age }=76.58, \\
67 \% \text { female }\end{array}$ & Recorded music & Standard care & $\begin{array}{l}\text { Patient- } \\
\text { administered }\end{array}$ & $\begin{array}{l}\text { VAS (0-100), } \\
\text { PRI }\end{array}$ \\
\hline $\begin{array}{l}\text { Onieva-Zafra et } \\
\text { al (2013) (36) }\end{array}$ & Spain & Fibromyalgia & $\begin{array}{l}\mathrm{n}=55 \\
\text { mean age }=51.6 \\
96 \% \text { female }\end{array}$ & Recorded music & Standard care & $\begin{array}{l}\text { Patient- } \\
\text { administered }\end{array}$ & $\begin{array}{l}\text { VAS }(0-10) \text {, } \\
\text { McGPQ, BDI }\end{array}$ \\
\hline $\begin{array}{l}\text { Seebacher et al } \\
(2016)(27)\end{array}$ & UK & $\begin{array}{l}\text { Multiple } \\
\text { Sclerosis }\end{array}$ & $\begin{array}{l}\mathrm{n}=112, \\
\text { mean age }=44.1, \\
76 \% \text { female }\end{array}$ & Recorded music & $\begin{array}{l}\text { Metronome + } \\
\text { standard care }\end{array}$ & $\begin{array}{l}\text { Patient- } \\
\text { administered }\end{array}$ & $\begin{array}{l}\text { VAS }(0-100) \text {, } \\
\text { BP }\end{array}$ \\
\hline $\begin{array}{l}\text { Siedliecki } \\
\text { (2006) (37) }\end{array}$ & USA & CNMP & $\begin{array}{l}\mathrm{n}=60 \\
\text { mean age }=49.7 \\
77 \% \text { female }\end{array}$ & Recorded music & Standard care & $\begin{array}{l}\text { Patient- } \\
\text { administered }\end{array}$ & $\begin{array}{l}\text { VAS }(0-10) \text {, } \\
\text { McGPQ, } \\
\text { CESD. }\end{array}$ \\
\hline $\begin{array}{l}\text { Weber et al } \\
(2015)(39)\end{array}$ & Brazil & Fibromyalgia & $\begin{array}{l}\mathrm{n}=120 \\
\text { mean age }=48.27 \\
100 \% \text { female }\end{array}$ & Recorded music & $\begin{array}{l}\text { Vibration points } \\
+ \text { standard care }\end{array}$ & $\begin{array}{l}\text { Patient- } \\
\text { administered }\end{array}$ & FIQ, HAQ \\
\hline
\end{tabular}

$\mathrm{CNMP}=$ chronic non-malignant pain (mechanical pain, inflammatory pain, fibromyalgia, neurological pain, osteoarthritis, herniated disc, rheumatoid arthritis, degenerative joint disease); VAS = visual analog scale; $\mathrm{pVAS}=$ pain visual analog scale; $\mathrm{mVAS}=$ mood visual analog scale; $\mathrm{BP}=$ biological parameters; $\mathrm{dNRS}=$ distress numeric rating scale; $\mathrm{pNRS}$ = pain numeric rating scale; HADS = hospital anxiety and depression scale; POMS = profile of mood states; FLACCS = face, legs, activity, cry, consolability scale; FPS = functional pain scale; ESAS = Edmonton symptom assessment system; $\mathrm{PRI}=$ pain rating index; $\mathrm{McGPQ}=\mathrm{McGill}$ Pain Questionnaire; $\mathrm{PPI}=$ present pain intensity; $\mathrm{BDI}=$ Beck depression inventory; $\mathrm{FIQ}=$ fibromyalgia impact questionnaire; $\mathrm{HAQ}=$ health assessment questionnaire; $0-10=10 \mathrm{~cm}$ scale; $0-100=100 \mathrm{~mm}$ scale 


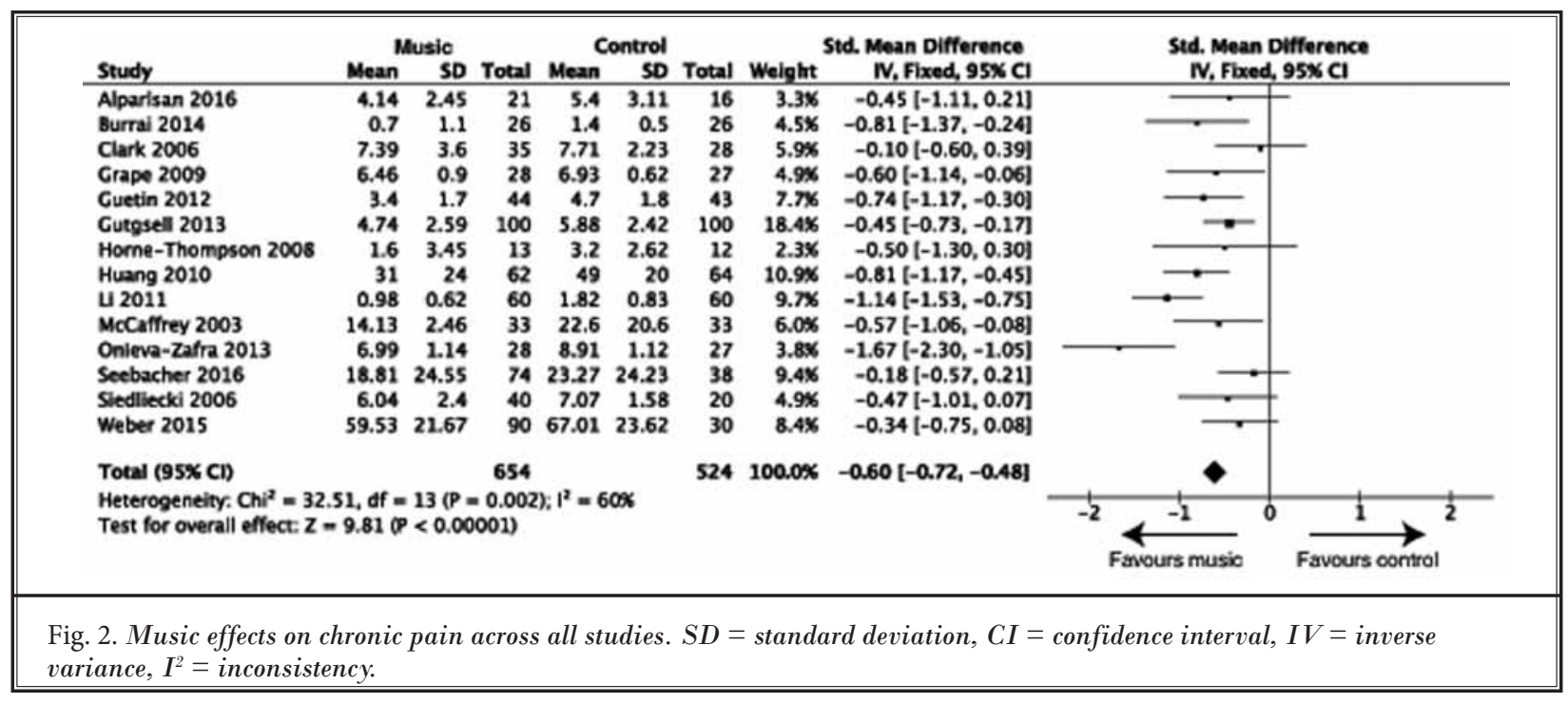

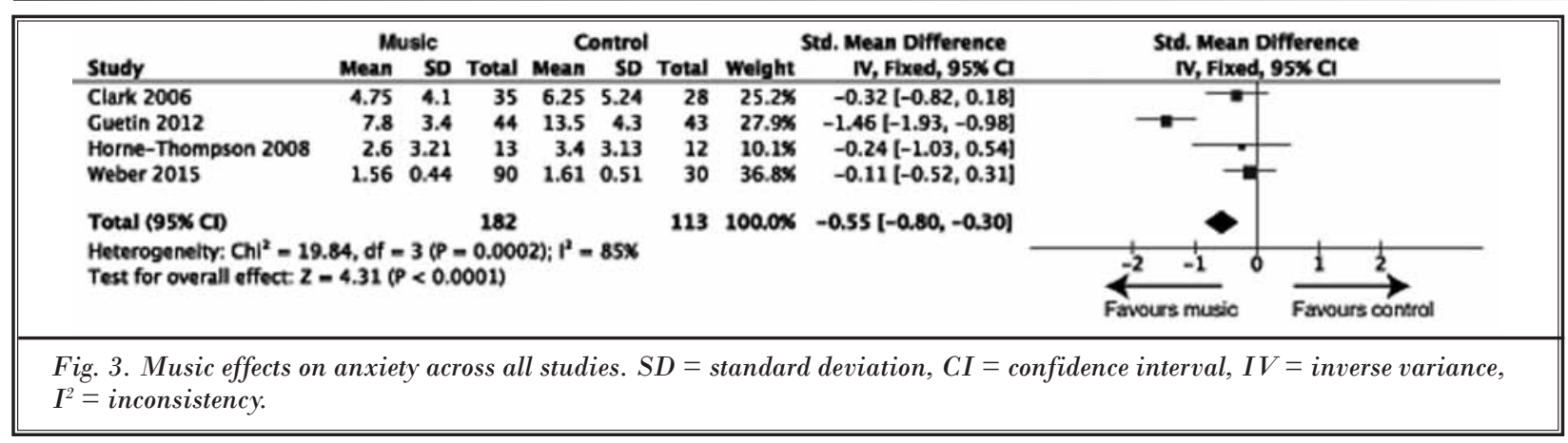

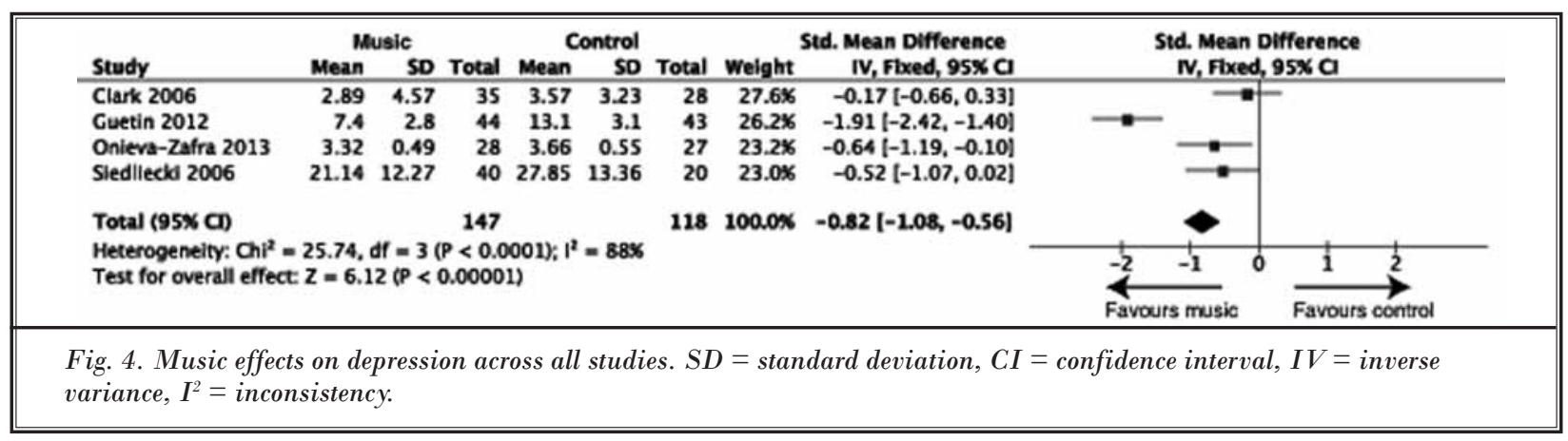

(42), the Fibromyalgia Impact Questionnaire (43), and the Health Assessment Questionnaire (44).

\section{Results}

We identified a total of 768 titles and abstracts, of which we reviewed 65 studies at full-text that reported music intervention for chronic pain (see PRISMA Fig. 1). We included 14 RCTs in the final qualitative and quanti- tative synthesis. Of the 14 studies included in the review, 11 investigated pain reduction as a primary outcome, while 3 investigated pain reduction as a secondary outcome. Other secondary outcomes included: anxiety, depression, fatigue, quality of life, disability, and biological parameters. We found that music reduced chronic pain in general (14 RCTs, standardized mean difference [SMD] $-0.60[-0.72,-0.48], Z=9.81, P<0.001$ ) (Fig. 2), 


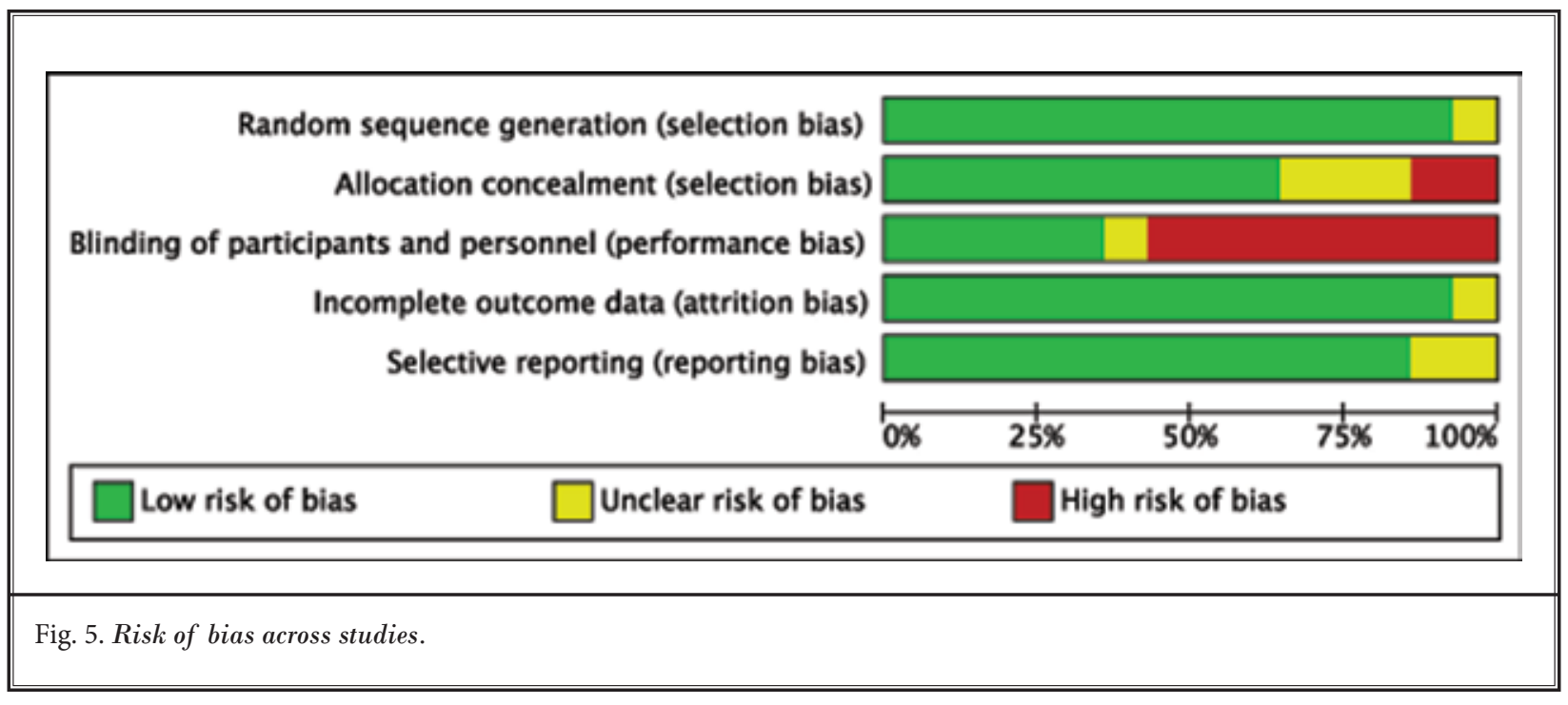

anxiety (4 RCTs, SMD $-0.55[-0.80,-0.30], \mathrm{Z}=4.31, P<$ 0.001 ) (Fig. 3), and depression (4 RCTs, SMD -0.82 [-1.08, -0.56], $Z=6.12, P<0.001$ ) (Fig. 4). The effect size was moderate for chronic pain and anxiety, while depression had a high size effect. Heterogeneity was high for pain, anxiety, and depression, with an $\mathrm{I}^{2}=60 \%$, $85 \%$, and $88 \%$, respectively. A domain-based evaluation was used as the tool for assessing risk of bias. The quality of studies was adequate for most of the included authors, with a low risk of bias overall (Fig. 5). Selection bias, attrition bias, and reporting bias had a low risk given that randomization was well performed, outcome data was complete, attrition was low, and all measured outcomes were reported. We found that performance risk of bias was moderate, due to lack of blinding for 8 of the 14 studies. Assessing for selection bias, we found moderate risk because the allocation concealment was not stated (3/14) or was not done (2/14) (Fig. 6).

\section{Subgroup Analysis}

The subgroup analysis by "etiology of pain" (Fig. 7) showed a non-significant $(P=0.17)$ higher effect size of music intervention when the pain etiology was neoplasm (4 RCTs, SMD -0.78 [-1.00, -0.56]) rather than degenerative/mechanical (2 RCTs, SMD -0.33 [-0.64, -0.03], inflammatory (one RCT, SMD -0.60 [-1.14, -0.06], unknown etiology (3 RCT, SMD $-0.68[-0.99,-0.38]$ ), and combined etiology (4 RCT, SMD - $0.52[-0.73,-0.32])$. The subgroup analysis "central vs. peripheral pain" showed no differences of music intervention $(P=0.81)$ between central pain (4 RCTs, SMD -0.66 [-0.93, -0.40]), peripheral pain (5 RCTs, SMD $-0.61[-0.80,-0.43]$ ), and studies with both central and peripheral pain (5 RCTs, SMD -0.56 $[-0.75,-0.36]$ ) (Fig. 8). In the "familiar vs. unfamiliar music" contrast, music had a non-significant $(P=0.11)$ higher effect size when musical pieces were familiar (6 RCTs, SMD $-0.72[-0.91,-0.53])$, when compared to unfamiliar music (8 RCTs, SMD -0.52 [-0.68, -0.36]) (Fig. 9). In the contrast "patient-selected vs. researcher-selected music," we found a significant greater effect size ( $P=$ 0.02 ) when the patients chose the music (5 RCTs, SMD $-0.81[-1.02,-0.59])$ than when the researchers chose the music (9 RCTs, SMD -0.51 [-0.65, -0.36]) (Fig. 10). Examining the funnel plot (Fig. 11) suggests that publication bias was not substantial as studies are evenly distributed either side of the SMD for chronic pain. Our risk of bias analysis shows a low risk overall (Fig. 5 \& 6).

\section{Heterogeneity}

Heterogeneity of effects was high across studies, probably due to several reasons: the use of different scales to measure pain, anxiety, and depression, the variability in the sample sizes, the variability of the pain etiology, the variability in the duration of the study, the type of music intervention of each study, and the type of music delivery (passive vs. active, patient-chosen vs. researcher-chosen). In the subgroup analysis "etiology of pain" (Fig. 5), the heterogeneity of studies that included combined etiology was null $\left(\mathrm{Chi}^{2}=1.20\right.$, df $=$ $\left.3,1^{2}=0 \%\right)$, and in studies with degenerative/mechanical processes the heterogeneity was low $\left(\mathrm{Chi}^{2}=1.47\right.$, df $\left.=1, I^{2}=32 \%\right)$ when compared with neoplasm (Chi ${ }^{2}$ 


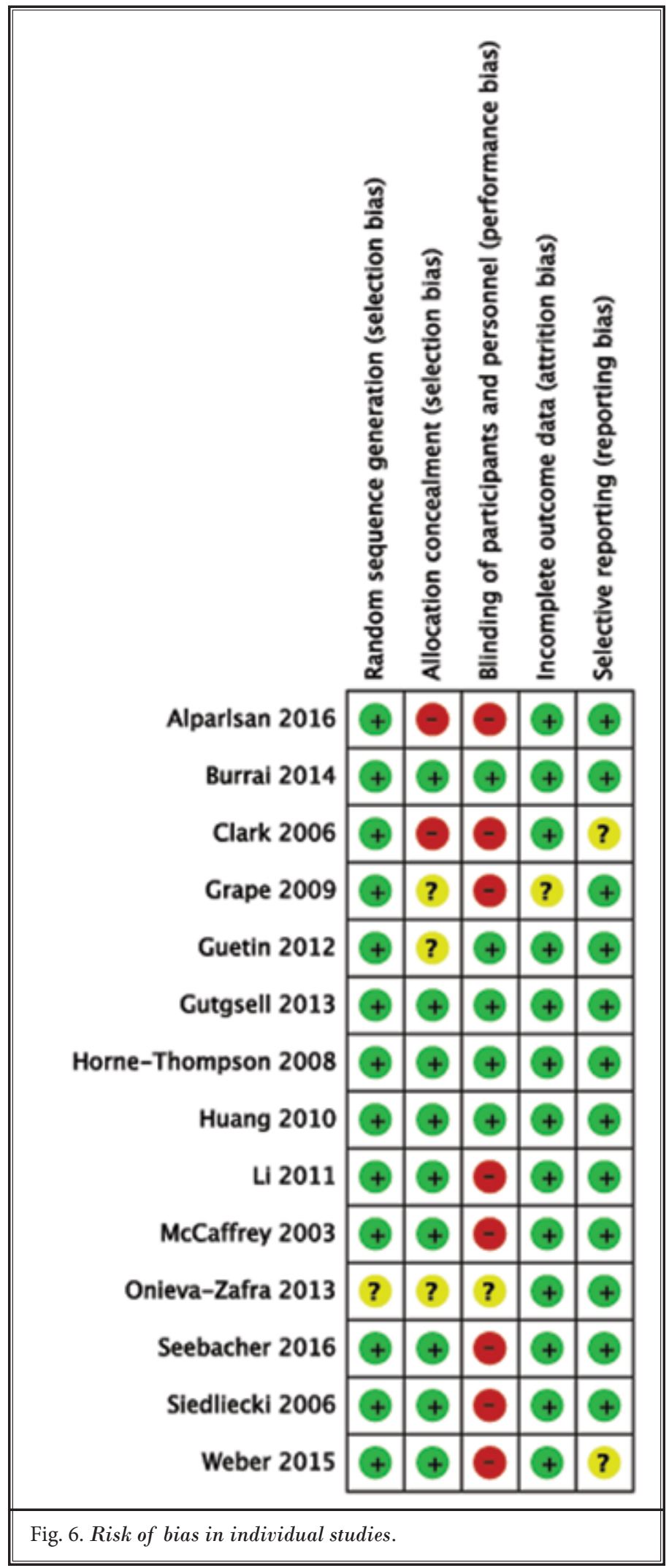

$\left.=10.47, \mathrm{df}=3, \mathrm{I}^{2}=71 \%\right)$ and unknown $\left(\mathrm{Chi}^{2}\right.$ $=12.99, \mathrm{df}=2, \mathrm{I}^{2}=85 \%$ ). Studies in the combined etiology subgroup assessed pain with a 0 - 10 VAS only, studied either CNMP (2/4) or palliative care (2/4), and evaluated both central and peripheral pain. A similar pattern occurred while analyzing heterogeneity in the subgroup "central vs. peripheral pain." Studies that included both central and peripheral pain showed no heterogeneity $\left(\mathrm{Chi}^{2}=2.04 \mathrm{df}\right.$ $=4, I^{2}=0 \%$ ). These studies used only a $0-10$ VAS. Heterogeneity was high for studies that included central pain $\left(\mathrm{Chi}^{2}=13.07, \mathrm{df}=3, \mathrm{I}^{2}=\right.$ $77 \%)$ and peripheral pain $\left(\mathrm{Chi}^{2}=16.99\right.$, df $=4$, $\left.I^{2}=76 \%\right)$, independently.

The ubgroup analysis of "familiar vs. unfamiliar music" showed substantial heterogeneity in both familiar $\left(\mathrm{Chi}^{2}=11.78, \mathrm{df}=5, \mathrm{I}^{2}=\right.$ $58 \%)$ and unfamiliar $\left(\mathrm{Chi}^{2}=18.19, \mathrm{df}=7, \mathrm{I}^{2}=\right.$ $62 \%$ ) music. A different pattern was shown in the subgroup "patient-chosen vs. researcherchosen music," where heterogeneity was low for patient-chosen music $\left(\mathrm{Chi}^{2}=5.00, \mathrm{df}=4\right.$, $\left.\mathrm{I}^{2}=20 \%\right)$, compared with researcher-chosen music $\left(\mathrm{Chi}^{2}=22.37, \mathrm{df}=8, \mathrm{I}^{2}=64 \%\right)$.

\section{Discussion}

This systematic review suggests that listening to music reduces self-reported pain, anxiety, and depression symptoms in a diverse range of chronic pain patients. We also found that music helped to reduce symptoms of anxiety and depression, common disabling comorbidities in chronic pain. In a subgroup analysis, we found that the analgesic effects of music were greater for patient-chosen than researcher-chosen music.

All of the included studies reported analgesic effects of music, and in general, these effects were significant, supporting the hypothesis that music is beneficial in chronic pain conditions. We suggest that the analgesic effect of music may initiate in the brain and elicits a top-down regulation mechanism via the DPMS, as it has been argued in fibromyalgia (11). Reductions in anxiety and depression symptoms, aside from the pain, are important effects, given that suicide is not uncommon in this patient sample. Music might improve patient coping with their condition, which at 


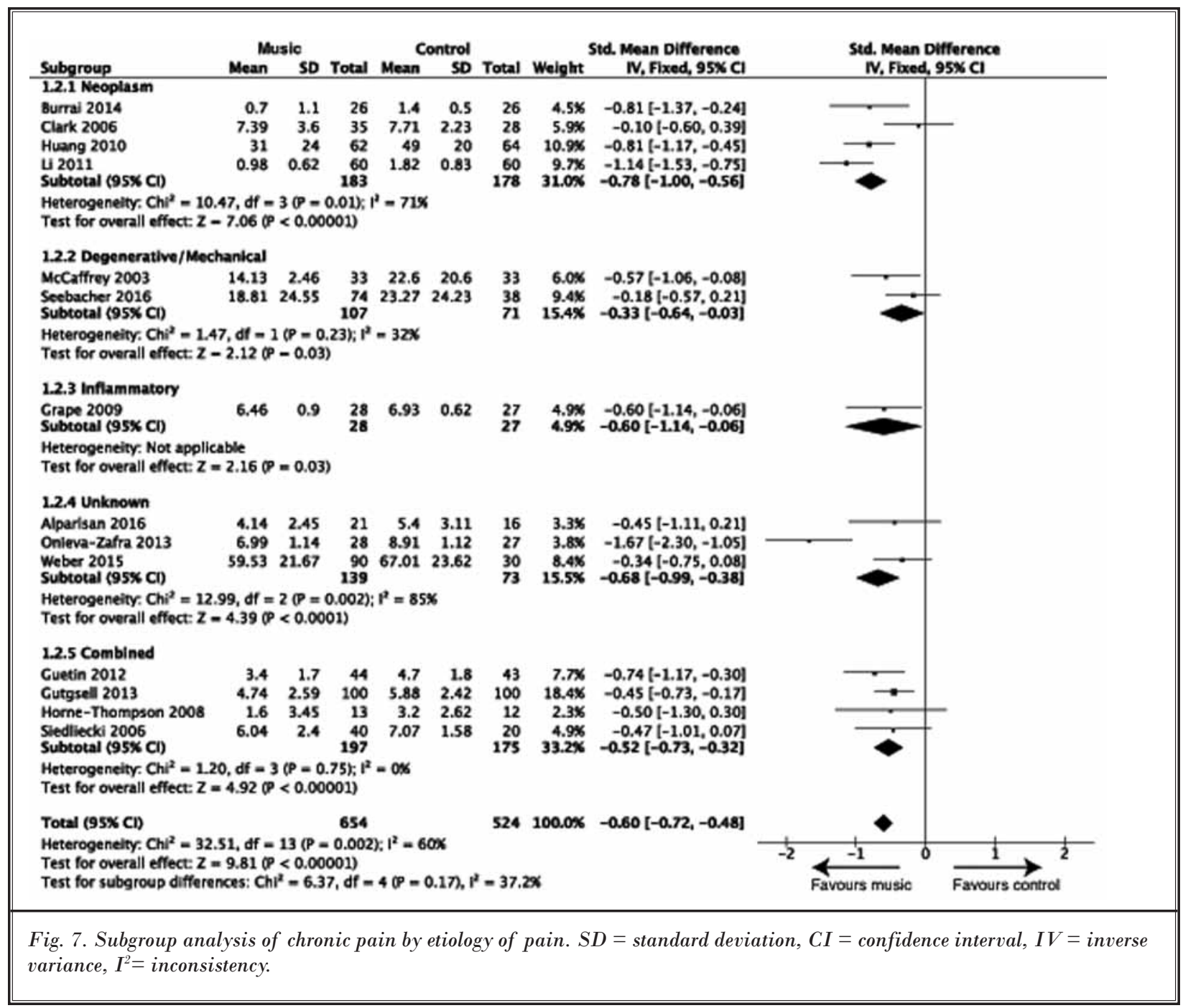

the same time may reduce feelings of helplessness and suicidal thoughts (45). It is not clear whether the reduction of anxiety and depression symptoms themselves could be secondary to the analgesic mechanism, but it is important to note that music seems to be positively contributing to more than one dimension and symptom of chronic pain.

\section{Subgroup Analysis}

We found no significant differences in response to music based on the etiology of pain or location of pain. Nevertheless, the studies we found did not include all types of pain (i.e., migraine) and more research is necessary to confirm our findings. One question of clear interest is how best to deliver a music intervention. In most of our included studies, the patients listened to music, only one study used active singing (31), and 2 studies used live music $(20,29)$. We therefore cannot make clear recommendations about the ideal mode of delivery of a music intervention. More studies are needed to assess if listening to recorded music (passive) provides similar benefits performing music (active) (Doelling \& Poeppel 2015). We found no significant difference in pain response to familiar (6/14) and unfamiliar music studies (8/14). This result contrasts with several experimental studies showing a higher analgesic effect of familiarity $(8,46)$. Listening to familiar music may induce a feeling of "control" of the situation and the expectation of musical "peaks" could induce pleasure and secondary analgesia and relaxation, as well as release dopamine and endogenous opioids (47). In an experimental study by our group we found that unfamiliar music provided 
Pain Physician: November/December 2017: 20: 597-610

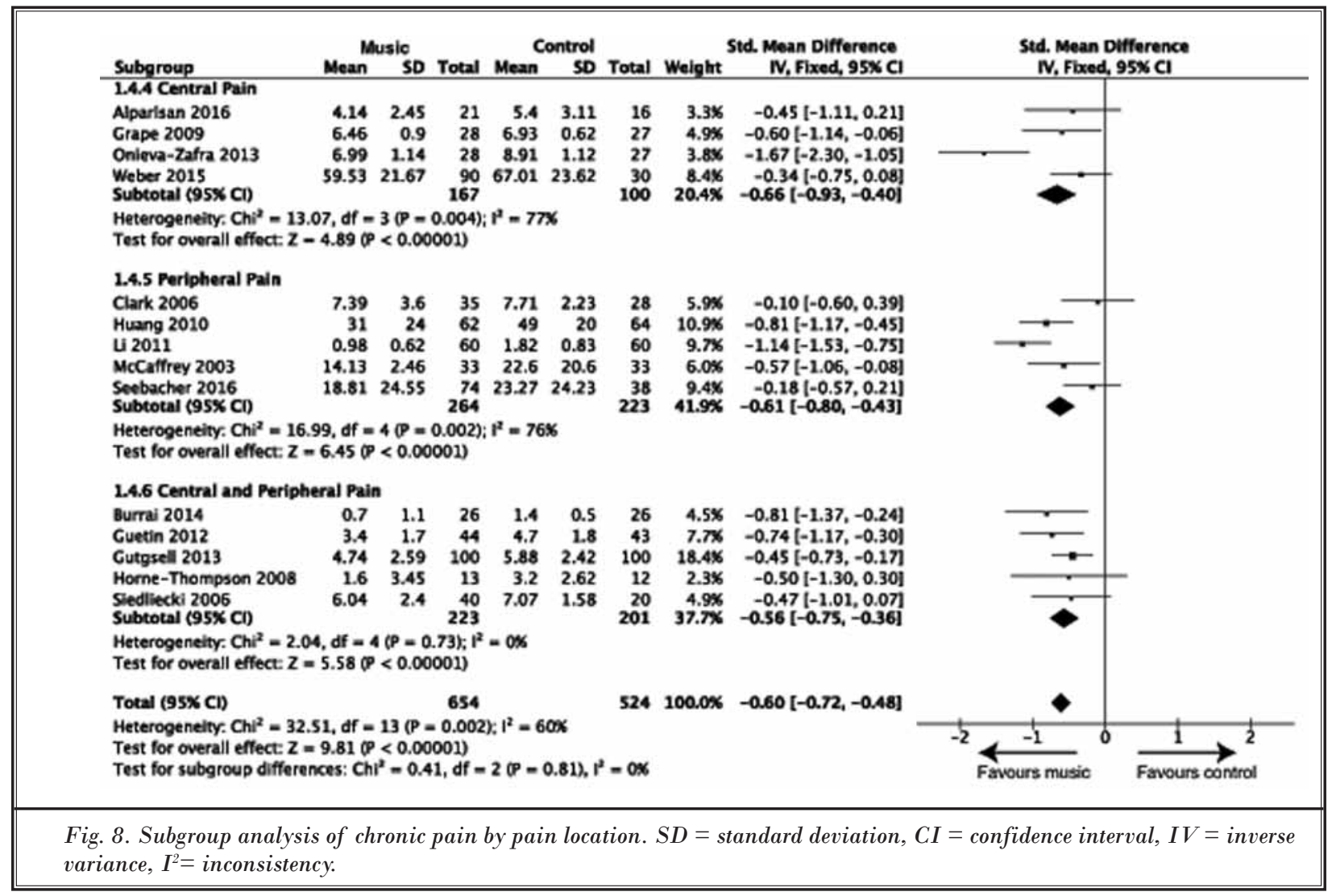

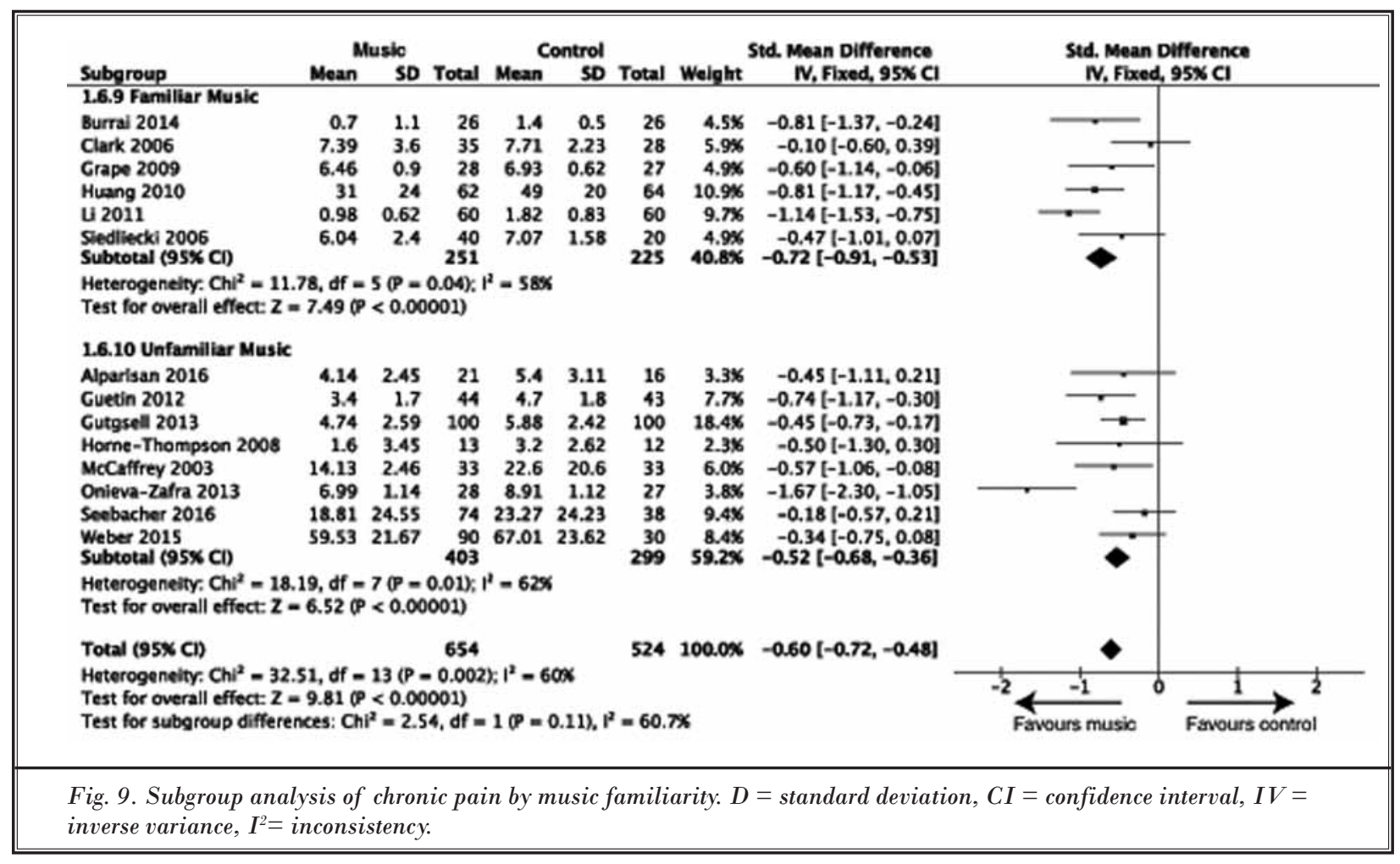




\begin{tabular}{|c|c|c|c|c|c|c|c|c|c|c|}
\hline & $\underset{\text { Mean }}{M}$ & $\begin{array}{l}\text { Iusic } \\
\text { SD }\end{array}$ & \multicolumn{3}{|c|}{ Control } & Total & Weight & \multirow[t]{2}{*}{$\begin{array}{l}\text { Std. Mean Difference } \\
\text { N, Flxed, 95\% Cl }\end{array}$} & \multicolumn{2}{|c|}{$\begin{array}{l}\text { Std. Mean Difference } \\
\text { N, Fbxed, } 95 \% \mathrm{CI}\end{array}$} \\
\hline \multicolumn{10}{|c|}{ 1.7.11 Researcher-chosen Music } & \\
\hline Alparlsan 2016 & 4.14 & 2.45 & 21 & 5.4 & 3.11 & 16 & $3.3 \%$ & $-0.45[-1.11,0.21]$ & & \\
\hline Clark 2006 & 7.39 & 3.6 & 35 & 7.71 & 2.23 & 28 & $5.9 \%$ & $-0.10[-0.60,0.39]$ & $\longrightarrow$ & \\
\hline Gutgsell 2013 & 4.74 & 2.59 & 100 & 5.88 & 2.42 & 100 & $18.4 \times$ & $-0.45[-0.73,-0.17]$ & $\because$ & \\
\hline Horne-Thompson 2008 & 1.6 & 3.45 & 13 & 3.2 & 2.62 & 12 & $2.3 \%$ & $-0.50[-1.30,0.30]$ & & \\
\hline Huang 2010 & 31 & 24 & 62 & 49 & 20 & 64 & $10.9 \%$ & $-0.81[-1.17,-0.45]$ & - & \\
\hline McCaffrey 2003 & 14.13 & 2.46 & 33 & 22.6 & 20.6 & 33 & $6.0 \%$ & $-0.57[-1.06,-0.08]$ & & \\
\hline Onieva-Zafra 2013 & 6.99 & 1.14 & 28 & 8.91 & 1.12 & 27 & 3.86 & $-1.67[-2.30,-1.05]$ & & \\
\hline Seebacher 2016 & 18.81 & 24.55 & 74 & 23.27 & 24.23 & 38 & $9.4 \%$ & $-0.18[-0.57,0.21]$ & & \\
\hline $\begin{array}{l}\text { Weber } 2015 \\
\text { Subtotal }(95 \% \mathrm{Cl})\end{array}$ & 59.53 & 21.67 & $\begin{array}{r}90 \\
456\end{array}$ & 67.01 & 23.62 & $\begin{array}{r}30 \\
348\end{array}$ & $\begin{array}{r}8.4 \% \\
68.3 \%\end{array}$ & $\begin{array}{r}-0.34[-0.75,0.08] \\
-0.51[-0.65,-0.36]\end{array}$ & & \\
\hline \multicolumn{11}{|c|}{$\begin{array}{l}\text { Heterogeneity: Chi }{ }^{2}=22.37 \text {, df }=8(P=0.004) ; P^{2}=64.6 \\
\text { Test for overall effect: } Z=6.83(p<0.00001)\end{array}$} \\
\hline \multicolumn{11}{|c|}{ 1.7.12 Participant-chosen Music } \\
\hline Burrai 2014 & 0.7 & 1.1 & 26 & 1.4 & 0.5 & 26 & $4.5 \%$ & $-0.81[-1.37,-0.24]$ & & \\
\hline Grape 2009 & 6.46 & 0.9 & 28 & 6.93 & 0.62 & 27 & $4.9 \%$ & $-0.60[-1.14,-0.06]$ & & \\
\hline Guetin 2012 & 3.4 & 1.7 & 44 & 4.7 & 1.8 & 43 & 7.78 & $-0.74[-1.17,-0.30]$ & & \\
\hline U 2011 & 0.98 & 0.62 & 60 & 1.82 & 0.83 & 60 & $9.7 \times$ & $6-1.14[-1.53,-0.75]$ & $\longrightarrow$ & \\
\hline $\begin{array}{l}\text { Sledlleckl } 2006 \\
\text { Subtotal (95\% Co) }\end{array}$ & 6.04 & 2.4 & $\begin{array}{r}40 \\
198\end{array}$ & 7.07 & 1.58 & $\begin{array}{r}20 \\
176\end{array}$ & $\begin{array}{r}4.9 \% \\
31.7 x\end{array}$ & $6 \begin{array}{r}-0.47[-1.01,0.07] \\
-0.81[-1.02,-0.59]\end{array}$ & & \\
\hline \multicolumn{11}{|c|}{$\begin{array}{l}\text { Heterogeneity, Chi }{ }^{2}-5.00, \text { df }-4(P-0.29) ; 1^{2}-206 \\
\text { Test for overall effect: } Z=7.39(P<0.00001)\end{array}$} \\
\hline Total $(95 \% \mathrm{Cl})$ & & & 654 & & & 524 & $100.0 \%$ & $6-0.60[-0.72,-0.48]$ & & \\
\hline \multicolumn{9}{|c|}{$\begin{array}{l}\text { Heterogeneity: } C h i^{2}=32.51 \text {, df }=13(P=0.002) ; 1^{2}=600 \mathrm{~K} \\
\text { Test for overall effect: } Z=9.81(P<0.00001) \\
\text { Test for subgroup differences: } C h 1^{2}=5.14, \mathrm{df}=1(P=0.02), \mathrm{I}^{2}=80.6 \mathrm{~K}\end{array}$} & $-2 \underset{\text { Favours music }}{-1} 0$ & $\underset{\text { Fawours contral }}{\stackrel{1}{2}}$ \\
\hline
\end{tabular}

less of an analgesic effect than an active math distraction (48). However, in this synthesis, we found that the effects of music familiarity were non-significant suggesting no effect or very low effect. This may be due to the small number of studies in our sample and should be studied further.

Evidence from other studies suggests that musical genre is not important for analgesic effects. While it was not possible to study music genre specifically, the included studies used a relatively wide range of genres. In our study, self-chosen music (5/14) had a significantly higher analgesic effect than researcher-chosen music (9/14). This effect has been reported by several experimental studies (13) and was also shown in another meta-analysis of music in cancer patients (23). This effect may be related to familiarity and the feeling of control and pleasure, thus contributing to the analgesic effect. The use of selfchosen music may present a challenge

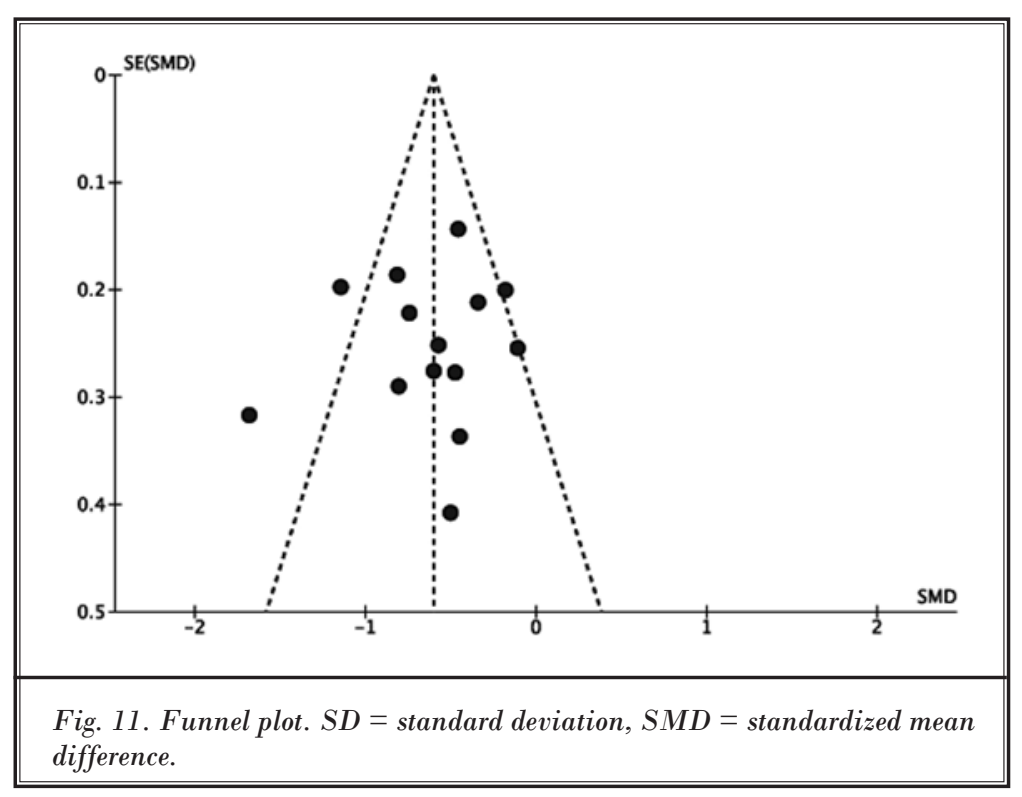

for standardizing music treatment, but having a pool of popular music choices could be one solution.

\section{Limitations}

The mean duration of the studies was 5 weeks $( \pm 3)$, and only one 
study lasted for a whole year (31). Only 4 studies did not report the duration of their whole intervention. The duration of the analgesic effect was not directly discussed in any study, but according to their results we suggest that a daily session of $20-30$ minutes, while experiencing pain exacerbation or not, is effective and recommended.

Due to the small number of studies, subgroup comparisons should be interpreted cautiously. In terms of study size, there was one RCT with an $n<35$, which would only have a power of 0.5 to detect a moderate effect size.

However, most outcome variables, primary and secondary, were measured using different instruments, which may partly explain the heterogeneity between studies. Several studies lacked complete information (i.e., pain measures and the type of music used). Also, there were many variable factors such as: the person who chose the music (patient-chosen vs. researcherchosen), the length of the music intervention (1 week to 12 months), the type of delivery of the music (active, passive listening, live music) and the type control condition, among others. Combining studies with different "control" interventions may not be ideal. The majority of our studies ( $n=11)$ used standard care as the comparison or control intervention, while only 3 used other types of comparisons (standard care + another). "Standard care" serves as an umbrella term that covers many potential treatments for pain. An ideal inactive control intervention would be to use a placebo intervention, analogue to pharmacological studies. However, it is not possible to tell a person "this is music" when it is, for example, "white noise." With this limitation, a possible control intervention should include an active or engaging activity similar to music in terms of contact time or engagement (i.e., listening to a preferred podcast or an audiobook), added to the standard care. When comparing a music intervention with this type of control intervention, we hypothesize lower effects sizes on pain reduction with music due to similar engagement and enjoyment.

In our sample, no study reported adverse or negative effects with music, and this could be either because there were none or because of inadequate reporting, which is typical for many psychological interventions (49). Nevertheless, we found a sample of RCTs with adequate sample sizes and overall effect sizes that provide consistent evidence in support of the reduction of pain, depression, and anxiety in chronic pain conditions, hence, supporting the use of music as an adjuvant in pain medicine.

Future RCTs should aim to use active control conditions, use more than one standard instrument (VAS, NRS, etc.), and to use self-chosen music to attempt to avoid heterogeneity. We still do not know the precise duration of the analgesic effect of music and the dosage of music intervention to produce a positive outcome, and these may explain part of the heterogeneity. Future studies should also record medication intake to assess for any reduction in the amount of painkillers or anxiety and depression medication after music intervention. While medication information was lacking in our study, it would be of clinical interest to examine the potential reduction in pain medication intake after music intervention. Reducing the intake amount of pain medication would improve the patients' quality of life by avoiding secondary effects such as gastrointestinal problems and prescribed drug dependency.

\section{Conclusions}

In this systematic review and meta-analysis, we show that music reduces self-reported pain, anxiety, and depression symptoms in chronic pain conditions. We show that self-chosen music has a higher analgesic effect than researcher-chosen music. We suggest that music can be used as an easily administered, effective adjuvant for chronic pain and its common comorbidities. Our systematic review and meta-analysis is the most complete to date on music and chronic pain patients, given the comprehensive search terms and study choice (RCTs). More studies are necessary to untangle specific questions about the mechanisms underlying the effect of music, and further studies should focus more on clinically important indices, such as the amount of medication taken after the music intervention. 


\section{References}

1. Nahin RL. Estimates of pain prevalence and severity in adults: United States, 2012.J Pain 2015; 16:769-780.

2. Dueñas $M$, Salazar A, Ojeda B, Fernández-Palacín F, Micó JA, Torres LM, Failde I. A nationwide study of chronic pain prevalence in the general Spanish population: Identifying clinical subgroups through cluster analysis. Pain Med 2015; 16:811-822.

3. Fayaz A, Croft P, Langford RM, Donaldson LJ, Jones GT. Prevalence of chronic pain in the UK: A systematic review and meta-analysis of population studies. BM] Open 2016; 6:e010364.

4. Vos T, Flaxman AD, Naghavi M, Lozano R, Michaud C, Ezzati M, Shibuya K, Salomon JA, Abdalla S, Aboyans V, Abraham J, Ackerman I, Aggarwal R, Ahn SY, Ali MK, Alvarado $M$, Anderson HR, Anderson LM, Andrews KG, Atkinson C, Baddour LM, Bahalim AN, Barker-Collo S, Barrero $\mathrm{LH}$, Bartels $\mathrm{DH}$, Basáñez MG, Baxter $A$, Bell $M L$, Benjamin EJ, Bennett $D$, Bernabé $E$, Bhalla $K$, Bhandari $B$, Bikbov B, Bin Abdulhak A, Birbeck G, Black JA, Blencowe $\mathrm{H}$, Blore JD, Blyth F, Bolliger I, Bonaventure A, Boufous S, Bourne R, Boussinesq M, Braithwaite T, Brayne C, Bridgett L, Brooker S, Brooks $\mathrm{P}$, Brugha TS, Bryan-Hancock C, Bucello C, Buchbinder R, Buckle G, Budke CM, Burch $M$, Burney $P$, Burstein R, Calabria $B$, Campbell B, Canter CE, Carabin H, Carapetis J, Carmona L, Cella C, Charlson $\mathrm{F}$, Chen H, Cheng AT, Chou D, Chugh SS, Coffeng LE, Colan SD, Colquhoun S, Colson KE, Condon J, Connor MD, Cooper LT, Corriere M, Cortinovis M, de Vaccaro KC, Couser W, Cowie BC, Criqui $\mathrm{MH}$, Cross M, Dabhadkar KC, Dahiya M, Dahodwala N, DamsereDerry J, Danaei G, Davis A, De Leo D, Degenhardt L, Dellavalle R, Delossantos A, Denenberg J, Derrett $S$, Des Jarlais DC, Dharmaratne SD, Dherani M, DiazTorne C, Dolk H, Dorsey ER, Driscoll T, Duber H, Ebel B, Edmond K, Elbaz A, Ali SE, Erskine H, Erwin PJ, Espindola $P$, Ewoigbokhan SE, Farzadfar F, Feigin $V$, Felson DT, Ferrari A, Ferri CP, Fèvre EM, Finucane MM, Flaxman S, Flood L, Foreman $\mathrm{K}$, Forouzanfar $\mathrm{MH}$, Fowkes FGR, Franklin R, Fransen M, Freeman MK, Gabbe BJ, Gabriel SE, Gakidou E, Ganatra HA, Garcia B, Gaspari F, Gillum RF, Gmel G, Gosselin R, Grainger R, Groeger J, Guillemin F, Gunnell D, Gupta R, Haagsma J, Hagan H, Halasa
YA, Hall W, Haring D, Haro JM, Harrison JE, Havmoeller R, Hay RJ, Higashi H, Hill C, Hoen B, Hoffman H, Hotez PJ, Hoy $D$, Huang JJ, Ibeanusi SE, Jacobsen $\mathrm{KH}$, James SL, Jarvis D, Jasrasaria R, Jayaraman S, Johns N, Jonas JB, Karthikeyan G, Kassebaum N, Kawakami N, Keren A, Khoo J-P, King CH, Knowlton LM, Kobusingye $\mathrm{O}$, Koranteng $\mathrm{A}$, Krishnamurthi $\mathrm{R}$, Lalloo R, Laslett LL, Lathlean T, Leasher JL, Lee YY, Leigh J, Lim SS, Limb E, Lin JK, Lipnick M, Lipshultz SE, Liu W, Loane M, Ohno SL, Lyons R, Ma J, Mabweijano J, Maclntyre MF, Malekzadeh R, Mallinger L, Manivannan S, Marcenes W, March L, Margolis DJ, Marks GB, Marks R, Matsumori A, Matzopoulos R, Mayosi BM, McAnulty JH, McDermott MM, McGill N, McGrath J, Medina-Mora ME, Meltzer M, Mensah GA, Merriman TR, Meyer A-C, Miglioli V, Miller M, Miller TR, Mitchell PB, Mocumbi AO, Moffitt TE, Mokdad AA, Monasta L, Montico M, Moradi-Lakeh M, Moran A, Morawska L, Mori R, Murdoch ME, Mwaniki MK, Naidoo K, Nair MN, Naldi L, Narayan KMV, Nelson PK, Nelson RG, Nevitt MC, Newton CR, Nolte S, Norman P, Norman R, O'Donnell M, O'Hanlon S, Olives C, Omer SB, Ortblad K, Osborne R, Ozgediz D, Page A, Pahari B, Pandian JD, Rivero AP, Patten SB, Pearce N, Padilla RP, Perez-Ruiz F, Perico N, Pesudovs K, Phillips D, Phillips MR, Pierce K, Pion S, Polanczyk GV, Polinder S, Pope CA, Popova S, Porrini E, Pourmalek F, Prince M, Pullan RL, Ramaiah KD, Ranganathan D, Razavi H, Regan M, Rehm JT, Rein DB, Remuzzi G, Richardson K, Rivara FP, Roberts $T$, Robinson C, De Leòn FR, Ronfani L, Room R, Rosenfeld LC, Rushton L, Sacco RL, Saha S, Sampson U, Sanchez-Riera L, Sanman E, Schwebel DC, Scott JG, Segui-Gomez M, Shahraz S, Shepard DS, Shin H, Shivakoti R, Singh D, Singh GM, Singh JA, Singleton J, Sleet DA, Sliwa K, Smith E, Smith JL, Stapelberg NJC, Steer A, Steiner T, Stolk WA, Stovner LJ, Sudfeld C, Syed S, Tamburlini G, Tavakkoli M, Taylor HR, Taylor JA, Taylor WJ, Thomas B, Thomson WM, Thurston GD, Tleyjeh IM, Tonelli M, Towbin JA, Truelsen T, Tsilimbaris MK, Ubeda C, Undurraga EA, van der Werf MJ, van Os J, Vavilala MS, Venketasubramanian $\mathrm{N}$, Wang $\mathrm{M}$, Wang W, Watt $\mathrm{K}$, Weatherall DJ, Weinstock MA, Weintraub R, Weisskopf MG, Weissman MM, White RA, Whiteford $\mathrm{H}$, Wiersma ST, Wilkinson
JD, Williams HC, Williams SRM, Witt E, Wolfe F, Woolf AD, Wulf S, Yeh PH, Zaidi AKM, Zheng Z-J, Zonies D, Lopez AD, Murray CJL, AlMazroa MA, Memish ZA. Years lived with disability (YLDs) for 1160 sequelae of 289 diseases and injuries 1990-2010: A systematic analysis for the Global Burden of Disease Study 2010. Lancet 2012; 380:2163-2196.

5. Maremmani I, Stefania C, Pacini M, Maremmani AG, Carlini M, Golia F, Deltito J, Dell'Osso L. Differential substance abuse patterns distribute according to gender in heroin addicts. J Psychoactive Drugs 2010; 42:89-95.

6. Tracey I, Dickenson A. Snapshot: Pain perception. Cell 2012; 148:1308-1308.e2.

7. Bingel U, Tracey I. Imaging CNS modulation of pain in humans. Physiology (Bethesda) 2008; 23:371-380.

8. Mitchell LA, MacDonald RA, Brodie EE. A comparison of the effects of preferred music, arithmetic and humour on cold pressor pain. Eur J Pain 2006; 10:343-351.

9. Roy M, Mailhot JP, Gosselin N, Paquette $S$, Peretz I. Modulation of the startle reflex by pleasant and unpleasant music. Int J Psychophysiol 2009; 71:37-42.

10. Roy M, Lebuis A, Hugueville L, Peretz I, Rainville P. Spinal modulation of nociception by music. Eur J Pain 2012; 16:870-877.

11. Garza-Villarreal EA, Wilson AD, Vase L, Brattico E, Barrios FA, Jensen TS, Romero-Romo JI, Vuust P. Music reduces pain and increases functional mobility in fibromyalgia. Front Psychol 2014; 5:90.

12. Tracey I. Getting the pain you expect: Mechanisms of placebo, nocebo and reappraisal effects in humans. Nat Med 2010; 16:1277-1283.

13. Mitchell LA, MacDonald RAR. An experimental investigation of the effects of preferred and relaxing music listening on pain perception. J Music Ther 2006; 43:295-316.

14. Mitchell LA, MacDonald RAR, Knussen C, Serpell MG. A survey investigation of the effects of music listening on chronic pain. Psychology of Music 2007; 35:37-57.

15. Legrain V, Damme SV, Eccleston C, Davis KD, Seminowicz DA, Crombez G. A neurocognitive model of attention to pain: Behavioral and neuroimaging evidence. Pain 2009; 144:230-232.

16. Roy M, Peretz I, Rainville P. Emotional valence contributes to music-induced 
analgesia. Pain 2008; 134:140-147.

17. Hsieh C, Kong J, Kirsch I, Edwards RR, Jensen KB, Kaptchuk TJ, Gollub RL. Well-loved music robustly relieves pain: A randomized, controlled trial. PLoS ONE 2014; 9:e107390.

18. Alparslan GB, Babadağ B, Özkaraman A, Yıldız P, Musmul A, Korkmaz C. Effects of music on pain in patients with fibromyalgia. Clin Rheumatol 2016; 35:1317-1321.

19. Finlay KA. Music-induced analgesia in chronic pain: Efficacy and assessment through a primary-task paradigm. Psychology of Music 2014; 42:325-346.

20. Gutgsell KJ, Schluchter M, Margevicius S, DeGolia PA, McLaughlin B, Harris M, Mecklenburg J, Wiencek C. Music therapy reduces pain in palliative care patients: A randomized controlled trial. J Pain Symptom Manage 2013; 45:822-831.

21. Hole J, Hirsch M, Ball E, Meads C. Music as an aid for postoperative recovery in adults: A systematic review and metaanalysis. Lancet 2015; 386:1659-1671.

22. van der Heijden MJ, Oliai Araghi S, van Dijk M, Jeekel J, Hunink MG. The effects of perioperative music interventions in pediatric surgery: A systematic review and meta-analysis of randomized controlled trials. PLoS One 2015; 10:e0133608.

23. Tsai HF, Chen YR, Chung MH, Liao YM, Chi MJ, Chang CC, Chou KR. Effectiveness of music intervention in ameliorating cancer patients' anxiety, depression, pain, and fatigue: A meta-analysis. Cancer Nurs 2014; 37: E35-E50.

24. Higgins JP, Green S. Cochrane Handbook for Systematic Reviews. http:// handbook-5-1.cochrane.org/.

25. Merskey H. Psychological approaches to the treatment of chronic pain. Postgrad Med J 1984; 60:886-892.

26. Burckhardt CS, Jones KD. Adult measures of pain: The McGill Pain Questionnaire (MPQ), rheumatoid arthritis pain scale (RAPS), short-form McGill Pain Questionnaire (SF-MPQ), verbal descriptive scale (VDS), visual analog scale (VAS), and West Haven-Yale Multidisciplinary Pain Inventory (WHYMPI). Arthritis Care Res 2003; 49:S96-S104.

27. Seebacher B, Kuisma R, Glynn A, Berger $T$. The effect of rhythmic-cued motor imagery on walking, fatigue and quality of life in people with multiple sclerosis: A randomised controlled trial. Mult Scler 2017; 23:286-296.

28. Review Manager (RevMan) [Computer program]. Version 5.3. Copenhagen: The Nordic Cochrane Centre, The Cochrane Collaboration, 2014.

29. Burrai F, Micheluzzi V, Bugani V. Effects of live sax music on various physiological parameters, pain level, and mood level in cancer patients: a randomized controlled trial. Holist Nurs Pract 2014; 28:301-311.

30. Clark M, Isaacks-Downton G, Wells N, Redlin-Frazier S, Eck C, Hepworth JT, Chakravarthy B. Use of preferred music to reduce emotional distress and symptom activity during radiation therapy. J Music Ther 2006; 43:247-265.

31. Christina Grape RN, Theorell T, Wikström BM, Ekman R. Choir singing and fibrinogen. VEGF, cholecystokinin and motilin in IBS patients. Med Hypotheses 2009; 72:223-225.

32. Guétin $S$, Giniès $P$, Siou DK, Picot $M C$, Pommié C, Guldner E, Gosp AM, Ostyn K, Coudeyre E, Touchon J. The effects of music intervention in the management of chronic pain: A single-blind, randomized, controlled trial. Clin J Pain 2012; 28:329-337.

33. Huang ST, Good M, Zauszniewski JA. The effectiveness of music in relieving pain in cancer patients: A randomized controlled trial. Int J Nurs Stud 2010; 47:1354-1362.

34. Li XM, Yan H, Zhou KN, Dang SN, Wang $D L$, Zhang YP. Effects of music therapy on pain among female breast cancer patients after radical mastectomy: Results from a randomized controlled trial. Breast Cancer Res Treat 2011; 128:411-419.

35. McCaffrey R, Freeman E. Effect of music on chronic osteoarthritis pain in older people. J Adv Nurs 2003; 44:517-524.

36. Onieva-Zafra MD, Castro-Sánchez AM, Matarán-Peñarrocha GA, Moreno-Lorenzo $C$. Effect of music as nursing intervention for people diagnosed with fibromyalgia. Pain Manag Nurs 2013; 14:e39-e46.

37. Siedliecki SL, Good M. Effect of music on power, pain, depression and disability. J Adv Nurs 2006; 54:553-562.

38. Horne-Thompson A, Grocke D. The effect of music therapy on anxiety in pa- tients who are terminally ill. J Palliat Med 2008; 11:582-590.

39. Weber A, Werneck L, Paiva E, Gans P. Effects of music in combination with vibration in acupuncture points on the treatment of fibromyalgia. J Altern Complement Med 2015; 21:77-82.

40. Zigmond AS, Snaith RP. The hospital anxiety and depression scale. Acta Psychiatr Scand 1983; 67:361-370.

41. Nekolaichuk C, Watanabe S, Beaumont C. The Edmonton Symptom Assessment System: A 15-year retrospective review of validation studies (1991-2006). Palliat Med 2008; 22:111-122.

42. Beck AT, Guth D, Steer RA, Ball R. Screening for major depression disorders in medical inpatients with the Beck Depression Inventory for Primary Care. Behav Res Ther 1997; 35:785-791.

43. Bennett R. The Fibromyalgia Impact Questionnaire (FIQ): A review of its development, current version, operating characteristics and uses. Clin Exp Rheumatol 2005; 23(5 Suppl 39):S154-S62.

44. Bruce B, Fries JF. The Stanford Health Assessment Questionnaire: Dimensions and practical applications. Health Qual Life Outcomes 2003; 1:20.

45. Campbell G, Darke S, Bruno R, Degenhardt $L$. The prevalence and correlates of chronic pain and suicidality in a nationally representative sample. Aust N Z J Psychiatry 2015; 49:803-811.

46. Plailly J, Tillmann B, Royet JP. The feeling of familiarity of music and odors: The same neural signature? Cereb Cortex 2007; 17:2650-2658.

47. Salimpoor VN, Benovoy M, Larcher K, Dagher A, Zatorre RJ. Anatomically distinct dopamine release during anticipation and experience of peak emotion to music. Nat Neurosci 2011; 14:257-262.

48. Garza Villarreal EA, Brattico E, Vase L, Østergaard L, Vuust P. Superior analgesic effect of an active distraction versus pleasant unfamiliar sounds and music: The influence of emotion and cognitive style. PLoS One 2012; 7:e29397.

49. Duggan C, Parry G, McMurran M, Davidson K, Dennis J. The recording of adverse events from psychological treatments in clinical trials: Evidence from a review of NIHR-funded trials. Trials 2014; 15:198. 